\title{
EFFECT OF THE JUVENILE HORMONE ON THE DEVELOPMENT OF THE MANDIBULAR GLAND IN WORKERS' PUPAE OF Apis mellifera $\mathrm{L}$. (HYMENOPTERA, APIDAE)
}

\author{
SALLES, H. C. and CRUZ-LANDIM, C. \\ Instituto de Biociências, Departamento de Biologia, UNESP, Av. 24 A, n. 1515, Bela Vista, \\ CEP 13506-900, Rio Claro, SP, Brazil \\ Correspondence to: Heliana Clara Salles, Instituto de Biociências, Departamento de Biologia, UNESP, Av. 24 A, \\ 1515, Bela Vista, CEP 13506-900, Rio Claro, SP, Brazil, e-mail: hcsalles@ rc.unesp.br \\ Received January 13, 2003 - Accepted April 25, 2003 - Distributed August 31, 2004
}

\begin{abstract}
Insect mandibular glands are exocrine organs that produce chemical substances known as pheromones that play an important role in intra-specific communication of insects. The mandibular glands of Apis mellifera, which are more highly developed in queens than in workers, present caste-specific polymorphism which seems to be regulated by the juvenile hormone $(\mathrm{JH})$. These glands develop at the pupation stage, during which the titer of $\mathrm{JH}$ is higher in queens. In spite of this observation, application recounted here of juvenile hormone on 5th-instar workers' larvae of Apis mellifera did not produce a significant effect on the size of the mandibular glands. Therefore, we may conclude that the response of insect organs to the exogenous application of $\mathrm{JH}$ varies according to the type of organ, its developmental program, and its developmental stage, as well as to the amount of hormone applied.
\end{abstract}

Key words: Apis mellifera, juvenile hormone, mandibular gland, development, bee.

\section{RESUMO}

\section{Efeito do hormônio juvenil sobre o desenvolvimento da glândula mandibular em pupas de operárias de Apis mellifera L. (Hymenoptera, Apidae)}

As glândulas mandibulares são órgãos exócrinos, produtores de substâncias químicas denominadas feromônios, cuja função é atuar na comunicação intra-específica. Essas glândulas apresentam polimorfismo casta-específico, o qual parece ser mediado pelo hormônio juvenil (HJ), e são mais desenvolvidas na rainha do que na operária. Seu desenvolvimento ocorre durante a pupação e, em rainhas, os níveis de HJ são mais altos. Apesar disso, aplicação experimental de hormônio juvenil em larvas de 5o instar de operárias de Apis mellifera não produziu efeito significativo sobre o tamanho das glândulas mandibulares. Pode-se concluir que a resposta dos órgãos das abelhas à aplicação exógena do HJ varia segundo o tipo de órgão, o programa e a fase de desenvolvimento do órgão analisado e o volume do hormônio utilizado.

Palavras-chave: Apis mellifera, hormônio juvenil, glândula mandibular, desenvolvimento, abelha.

\section{INTRODUCTION}

The mandibular glands of Apis mellifera are exocrine glands responsible for the production of pheromones, which play a direct role in communication among members of the colony. The man- dibular glands arise during pupation (Cruz-Landim $\&$ Melo, 1967) and, therefore, their development is directly or indirectly under the effect of the juvenile hormone $(\mathrm{JH})$.

These glands present different sizes and functions in workers and queens of $A$. mellifera, being 
larger in the queens (Snodgrass, 1956; Cruz-Landim, 1967; Gracioli \& Silva de Moraes, 2002a). The mandibular glands are paired organs located at the proximal portion of the mandibles. The excretory orifice of these glands can be found at the internal face of the membrane that joins the mandible to the head, thus serving to spread the secretion into the spatular region of the mandible.

Under the light microscope, the mandibular glands of A. mellifera appear as sac-shaped structures, presenting an epithelium of flattened cells that delimits a central reservoir (Vallet et al., 1991; Lensky \& Cassier, 1995). The epithelial cells are classified as Class III glandular cells (Noirot \& Quennedey, 1991; Quennedey, 1998).

The juvenile hormone $(\mathrm{JH})$ is produced by the corpora allata and acts morphogenetically, thus influencing larval development and the general metabolism of the adult insect. Rachinsky et al. (1990) compared the differences in the JH levels among honeybee castes. A caste-specific difference in the hormonal level was noted at two developmental moments: 1) the peak in the titer of $\mathrm{JH}$ occurring in queens at the beginning of the 5th larval instar (last larval instar) that is much higher than it is in workers, a difference which diminishes progressively until the cocoon-spinning stage, but remains slightly higher in the queens; 2 ) the peak in the titer of $\mathrm{JH}$ that is observed for both castes at the pre-pupae stage; during this peak, the JH level is still higher in queens than it is in workers but not as high as the previous peak. This increase of $\mathrm{JH}$ level probably serves to regulate the pupal molt. Afterwards, the JH titer decreases abruptly in both castes, disappearing at the stage of white-eyed pupae.

Rachinsky \& Engels (1995) suggested that the peak in JH titer that corresponds to the beginning of the 5th instar of the queen larva occurs about two days prior to the appearance of the first evident physical signs of the future queen.

In the adult, the JH level also varies according to the needs of the insect (Akamatsu et al., 1975; Hartfelder \& Engels, 1998). This variation promotes the general control of metabolism, caste polymorphism, reproduction, age polyethism, physiology, and also influences the ovarian activity of the females (Akamatsu et al., 1975; Nóvak, 1975; Rembold, 1976; Noirot, 1977; Bonetti et al., 1994). The juvenile hormone has a general trophic action similar to that of the growth hormone secreted by the hypophysis of vertebrates.
In honeybees, only $\mathrm{JH}$ III is found during all three developmental stages (larva, pupa, and adult). The JH I might be detected in limited amounts while JH II is completely absent from all developmental stages of these bees (Hagenguth \& Rembold, 1978).

Huang et al. (1991) showed that the differences in the $\mathrm{JH}$ titers in honeybees depend on the age of the individual and the synthesis of this hormone by the corpora allata. Later, Robinson et al. (1991), Huang et al. (1991), Cassier \& Lensky (1991), and Vallet et al. (1991) claimed that a relationship exists between the behavioral development of bees and their age and $\mathrm{JH}$. titer.

That $\mathrm{JH}$ affects the division of labor in bees has also been verified. In young bees involved in tasks inside the nest, lower titers of JH have been found (Fluri et al., 1982) than those of bees that perform tasks outside the nest, such as foraging (Robinson et al., 1989; Plettner et al., 1997).

Abdalla \& Cruz-Landim (2001) showed that the Dufour gland is inactive in nurse workers and attributed this to the low titer of juvenile hormone found in the hemolymph of the bee, as well as to the direct contact between worker and queen. The Dufour gland is more developed in egg-laying queens and forager bees, individuals that show high JH titers.

An experiment consisting of $\mathrm{JH}$ topical application on last-instar larvae of honeybees resulted in increased development of the Dufour gland in newly emerged workers; the opposite effect was observed for the Koschewnikow gland, which had its cellular area reduced (Abdalla et al., 2001). Abdalla \& Cruz-Landim (2001) noted that the physical characteristics of the Dufour gland were indicative of precocious maturation in adults of $A$. mellifera that received JH topical application. On the other hand, Muller \& Hepburn (1994) observed no effect on the wax production rate of the same bee receiving a similar treatment, thus indicating that the hormone did not alter glandular activity.

The object of this work was to verify whether or not there is an alteration of the regular pattern of glandular development of the mandibular gland in response to an increase of JH level in workers' larvae of Apis mellifera.

\section{MATERIALS AND METHODS}

The 5th instar workers' larvae of Africanized Apis mellifera $\mathrm{L}$ were obtained from a single oviposition of the same queen from a colony maintained 
at the apiary of the Departamento de Biologia of the Universidade Estadual Paulista (UNESP, at Rio Claro Campus, São Paulo State, Brazil).

A comb containing individuals of the 5th larval instar was collected and divided into six smaller pieces $\left(\mathrm{F}_{1}, \mathrm{~F}_{2}, \mathrm{~F}_{3}, \mathrm{~F}_{4}, \mathrm{~F}_{5}\right.$, and $\left.\mathrm{F}_{6}\right)$; individuals in each of these comb pieces received a different treatment, as described below.

Experiment 1: $\mathrm{F}_{1}=$ control group $(\mathrm{C}), \mathrm{F}_{2}=$ larvae treated with the topical application of $1 \mu \mathrm{l}$ of acetone (AT), and $\mathrm{F}_{3}=$ larvae treated with the topical application of $1 \mu \mathrm{g}$ of JH III (Sigma) diluted in $1 \mu \mathrm{l}$ of acetone (JHT).

The larvae continued their development in an incubator with controlled temperature and humidity, as suggested by Salles (2002).

The adult bees were collected right after emergence, at which time the mandibular gland is completely developed. The mandibular glands of each individual were dissected and histologically processed following standard procedures. Sequential sections of $5 \mu \mathrm{m}$ each were obtained for each pair of glands and arranged on histological slides. The slides were then stained with hematoxylin and eosin (HE). The areas of 90 median sections of glands from individuals of each of the three groups mentioned were measured, making totaling 270 median glandular areas measured.

Experiment 2: $\mathrm{F}_{4}=$ control group $(\mathrm{C}), \mathrm{F}_{5}=$ larvae treated with a topical application of $1 \mu \mathrm{l}$ of hexane $(\mathrm{HT})$, and $\mathrm{F}_{6}=$ larvae treated with the topical application of $1 \mu \mathrm{g}$ of JH III (Sigma) diluted in 1 $\mu \mathrm{l}$ of hexane (JHT).

After treating the larvae, the combs were placed in an incubator with controlled temperature and humidity, as suggested by Salles (2002). Insect development continued until the emergence of the adult workers, which were then collected, and their mandibular glands dissected and fixed in Bouin mixture.

The area of 60 glands from each group was measured, totaling 180 measurements. As the measuring parameter for this experiment we used the convex surface area, which is the glandular face in front of the compound eye.

The gland areas obtained in experiments 1 and 2 were measured using Manager-IMPACT (Graphic Applications) adapted to an Axioskop (Zeiss) light microscope with an Axiohome system. The area values obtained $\left(\mu \mathrm{m}^{2}\right)$ for each group of each experiment were statistically compared through an analysis of variance and a Tukey test.

\section{RESULTS}

For experiment 1 , the analysis of variance detected a significant difference $(\mathrm{p}<0.05)$ among the groups, with $\mathrm{p}=0.00034$ and $\mathrm{F}=8.23$. The Tukey test detected significant differences among the groups JHT and AT and between AT and C. The coefficients of variation of the groups were $35 \%$ for C, $28 \%$ for AT, and $29 \%$ for JHT. Therefore, we conclude that the samples present a representative and reliable dispersion pattern $(<50 \%)$ (Table 1$)$.

In experiment 2, no significant differences were observed among the groups since the mean areas of the groups were very similar. The values of the coefficient of variation were very low, thus indicating uniformity in distribution of the samples for each group. The coefficients of variation for each group were: $12 \%$ for group C, $16 \%$ for group HT, and $20 \%$ for group JHT (Table 2).

TABLE 1

Experiment 1: Tukey test of the mean areas obtained from the median sections of the mandibular glands $\left(\mu \mathrm{m}^{2}\right)$ of newly emerged workers of Apis mellifera in three experimental groups. $\mathrm{C}=$ control group, $\mathrm{AT}=$ group treated with acetone, JHT $=$ group treated with JH III.

\begin{tabular}{|c|c|c|c|}
\hline \multirow{2}{*}{ Tukey test } & \multicolumn{3}{|c|}{ Mandibular gland } \\
\cline { 2 - 4 } & Mean (C) & Mean (AT) & Mean (JHT) \\
\hline & $284,347.8$ & $246,198.9$ & $296,633.3$ \\
\hline C & & $0.009135^{*}$ & 0.610091 \\
\hline AT & $0.009135^{*}$ & & $0.00310^{*}$ \\
\hline JHT & 0.610091 & $0.000310^{*}$ & \\
\hline
\end{tabular}

*Significant differences $(\mathrm{p}<0.05)$. 
TABLE 2

Experiment 2: Analysis of variance of the mean areas $\left(\mu \mathbf{m}^{2}\right)$ of whole mandibular glands of newly emerged workers of Apis mellifera in three experimental groups. $\mathrm{C}=$ control group, $\mathrm{HT}=$ group treated with hexane, JHT = group treated with JH III.

\begin{tabular}{|c|c|}
\hline \multirow{2}{*}{$\begin{array}{c}\text { Mandibular } \\
\text { glands }\end{array}$} & $\begin{array}{c}\text { Anova } \\
(\mathbf{F}=\mathbf{0 . 4} ; \mathbf{p}=\mathbf{0 . 9 6})\end{array}$ \\
\cline { 2 - 2 } & Means \\
\hline $\mathrm{C}$ & $302,000.31$ \\
\hline HT & $304,000.80$ \\
\hline JHT & $302,000.85$ \\
\hline
\end{tabular}

$\mathrm{p}>0.05=$ no significant differences.

\section{DISCUSSION}

As pointed out in the introduction, the mandibular glands of queens of Apis mellifera are much larger than those of workers and $\mathrm{JH}$ action, which is present in higher levels in queens, accounts for this caste differentiation. Our hypothesis was that extra doses of the hormone applied to workers' larvae would stimulate glandular development similar to that seen in the mandibular glands of queens.

Nevertheless, the experimental application of $\mathrm{JH}$ on 5 th instar larvae of $A$. mellifera did not produce a statistically significant effect on the size of workers' mandibular glands. In Experiment 1 we observed that acetone apparently inhibits glandular growth and could be counteracting the JH effect. Therefore, we decided to substitute that solvent by hexane in the next experiment. In Experiment 2 we observed that the extra $\mathrm{JH}$ dose also did not affect the final size of the mandibular gland.

The lack of an effect of JH application on the differentiation of workers' mandibular glands has two possible explanations:

1. The JH volume used was not sufficient to provoke an alteration in the developmental pattern of the gland.

2. The mandibular gland is not susceptive to $\mathrm{JH}$ at the stage during which the hormone was applied. In other words, the expression of the genes that will determine the physical characters of a queen or worker is turned on before the 5th instar.

The second alternative seems the most likely, since the dosage of the hormone used in this work has proved effective in similar experiments with honeybees (Liu, 1989; Bonetti et al., 1994; Abdalla et al., 2001; Paes de Oliveira \& Cruz-Landim, 2001). Considering that the hormonal dose applied was insufficient, we may conclude that the response of the different organs of the bee to the exogenous application of JH might vary according to the time of application, the type and amount of hormone used, and also to the initial developmental program of the organ under study. These observations have been verified by several other authors (Abdalla et al., 2001; Gracioli \& Silva de Moraes, 2002b; Nocelli et al., 2002).

Acknowledgements - The authors wish to thank the Fundação de Amparo à Pesquisa do Estado de São Paulo - FAPESP (Proc. 96/12744-7) - for financial support.

\section{REFERENCES}

ABDALLA, F. C., GRACIOLI, L. F., SALLES, H. C., CRUZ LANDIM, C. \& SILVA DE MORAES, R. L. M., 2001, Effect of application of juvenile hormone $(\mathrm{JH})$ in honeybee worker larvae on the development of the Dufour's and Koschewnikow's glands. Sociobiology, 37(1): 185-191.

ABDALLA, C. A. \& CRUZ-LANDIM, C., 2001, Changes in the morphology of the Dufour gland of Apis mellifera $\mathrm{L}$. (Hymenoptera, Apinae, Apini) during the life stages of the female castes. Rev. Bras. Entomol., 45(2): 123-129.

AKAMATSU, Y., DUNN, P. E., KEZDY, F. J., KRAMER, K. J., LAW, J. H., RUBSTEIN, D. \& SANBURG, L. L., 1975, Biochemical aspects of juvenile hormone action in insects, pp. 123-149. In: R. Meinst \& E. Davies (eds.), Control mechanisms in development. Phenum Publishing Corporation, New York.

BONETTI, A. M., CRUZ-LANDIM, C. \& KERR, W. E., 1994 Sex determination in bees XXX. Effects of juvenile hormone on the development of tergal glands in Melipona. Journal of Apicultural Reserch., 33(1): 11-14. 
CASSIER, P. \& LENSKY, Y., 1991, Ëvolution du titre de l'hormone juvénile III, des ecdystéröides et d'une phéromone, la 2 heptanone, en relation avec le polyéthisme des ouvirières ed l'abeille domestique (Apis melifera L. var ligustica) Hymenoptera, Apidae). C. R. Acad. Sci: Paris, T.312, série III, pp. 343-348.

CRUZ-LANDIM, C., 1967, Estudo comparativo de algumas glândulas de abelhas (Hymenoptera, Apoidea) e respectivas implicações evolutivas. Arq. Zool., 15: 117-290.

CRUZ-LANDIM, C. \& MELLO, M. L. S., 1967, Post-embryonic changes in Melipona quadrifasciata anthidioides Lep (Hymenoptera, Apoidea). II Development of the salivary glands system. Journal of Morph., 123(4): 481-502.

FLURI, P., LÜSCHER, M., WILLW, H. \& GERIG, L., 1982, Changes in weight of the pharyngeal gland and haemolymph titers of juvenile hormone, protein and vitellogenin in worker honey bees. J. Insect Physiol., 28: 61-68.

GRACIOLI, L. F. \& SILVA DE MORAES, R. L. M., 2002a, Histological and morphometric comparisons of worker and queen mandibular glands of Melipona bicolor bicolor (Hymenoptera, Meliponini). Sociobiology, 40(2).

GRACIOLI, L. F. \& SILVA DE MORAES, R. L. M., 2002b, Juvenile hormone promotes changes in the expression of hypopharingeal gland proteins of worker Apis mellifera (Hymenoptera: Apidae). Sociobiology, 40(2).

HAGENGUTH, H. \& REMBOLD, H., 1978, Identification of juvenile hormone III as the only J.H. homolog in all developmental stages of honeybee. Z. Naturforsch., 33c: 847-850.

HARTFELDER, K. \& ENGELS, W., 1998, Social insect polymorphism: hormonal regulation of plasticity in development and reprodution in the honeybee. Current topics in developmental biology, 40: 45-77.

HUANG, Z. Y., ROBSON, G. E., TOBE, S. S., YAGI, K. J., STRAMBI, A. \& STAY, B., 1991, Hormonal regulation of behavioural development in the honey bee based on changes in the rate of juvenile hormone biosynthesis. Journal of Insect Physiology, 37(10): 733-742.

LENSKY, Y. \& CASSIER, P., 1995, The alarm pheromones of queen and worker honey bees. Bee World, 76(3): 119-129.

LIU, T. T., 1989, Juvenile hormone III induced ultrastructural changes in the hypopharyngeal glands of honeybee Apis mellifera L. (Hymenoptera, Apidae) without and with infection by Nosema apis zander (Microsporidae: Nosematidae). $J$. Insect Morphol. \& Embryol., 18(2/3): 78-83.

MULLER, W. J. \& HEPBURN, H. R., 1994, Juvenile hormone III and wax secretion in honeybees (Apis mellifera capensis). J. Insect. Physiol., 40(10): 873-881.

NOCELLI, R. C. F., ROAT, T. C. \& SILVA DE MORAES, R. L. M., 2002, Alterations induced by juvenile hormone in glandular cells of the Apis mellifera venon gland. Applications on the larvae (Hymenoptera: Apidae). Sociobiolgy, 40(2).

NOIROT, C., 1977, Various aspects of hormone action in social insects. Proc. III Int. Congr. IUSSI, pp. 12-16.
NOIROT, C. \& QUENNEDEY, A., 1991, Glands, gland cell, glandular units: some comments on terminology and classification. Na. Soc Ent. Fr. (NS), 27(2): 123-128.

QUENNEDEY, A., 1998, Insect epidermal gland cells: Ultrastructure and morphogenesis. In: F. W. Harrison, M. Locke (eds.), Microscopic anatomy of invertebrates, insects. Wiley-Lis, London, 11A: 177-207.

NÓVAK, V. J. A., 1975, Insect hormones. Chapman \& Hall, London, 600p.

PAES DE OLIVEIRA, V. T. \& CRUZ-LANDIM, C., 2001, Experimental control of the effect of extra doses of juvenile hormone on bee development: The case of the wax glands of Apis mellifera (Hymenoptera: Apidae). Sociobioloy, 38(3A).

PLETTNER, E., OTIS, G. W., WIMALARATNE, P. D. C., WINSTON, M. L., SLESSOR, K. N., PANKIN, T. \& PUNCHIHEWA, P. W. K., 1997, Species and castedetermined mandibular gland signals in honeybees (Apis). J. Chem. Ecol., 23(2): 363-377.

RACHINSKY, A., STRAMBI, C., STRAMBI, A. \& HARTFELDER, K., 1990, Caste and metamorphosis haemolymph titers of juvenile hormone and ecdysteroids in last instar honeybee larvae. Gen. Comp. Endocrinol., 79: 31-38.

RACHINSKY, E. \& ENGELS, W., 1995, Caste development in honeybees (Apis mellifera): Juvenile hormone turns on ecdysteroids. Naturwissenschaften, 82: 378-379.

REMBOLD, H., 1976, The Role of determination in caste formation in the honeybee. In: M. Lüscher (ed.), Phase and caste determination in insects- endocrines aspects. Papers presented at a Symposium of the Physiology and Biochemistry Section of the XV International Congress of Entomology, Washington D.C., Pergamon Press, pp. 21-34.

ROBINSON, G. E., ROBINSON, G. E., PAGE, R. E., STRAMBI, C. \& STRAMBI, A., 1989, Hormonal and genetic control behavioral integration in honey bee colonies. Science, 246 : 109-112.

ROBINSON, G. E., STRAMBI, C., STRAMBI, A. \& FELDLAUFER, M. F., 1991, Comparison of juvenile hormone and ecdysteroid haemolymph titres in adult worker and queen honey bees (Apis mellifera). J. Insect Physiol., 37(12): 929-936.

SALLES, H. C., 2002, A method for rearing immature stage of Apis mellifera outside the colony (Hymenoptera: Apidae). Sociobiology, 39(2): 187-193.

SNODGRASS, R. E., 1956, Anatomy of the honey bee. Constock Publishing Associate, New York, 334p.

VALLET, A., CASSIER, P. \& LENSKY, Y., 1991, Ontogeny of the fine-structure of the mandibular glands of the honeybee (Apis mellifera $\mathrm{L}$.) workers and pheromonal activity of 2heptanone. Journal of Insect Physiology, 37(11): 789-804. 